\title{
Estimating historical land use patterns in Amazonia for hydrological studies
}

The evaluation of the impacts of land-use change on the water resources has been, many times, limited by the knowledge of past land use conditions. Most publications on this field present only a vague description of the past land use, which is usually insufficient for more comprehensive studies. This study presents the first reconstruction of the historical land use patterns in Amazonia, that includes both croplands and pasturelands, for the period 1940-1995. During this period, Amazonia experienced the fastest rates of land use change in the world, growing 4-fold from 193,269 km2 in 1940 to $724,899 \mathrm{~km} 2$ in 1995. This reconstruction is based on a merging of satellite imagery and census data, and provides a 5' $\times 5$ ' yearly dataset of land use in three different categories (cropland, natural pastureland and planted pastureland) for Amazonia. This dataset will be an important step towards understanding the impacts of changes in land use on the water resources in Amazonia.

Keywords: Amazonia; Pasturelands; Watersheds; Land use Change.

\section{Estimando padrões históricos de uso da terra na Amazônia para estudos hidrológicos}

\begin{abstract}
A avaliação dos impactos da mudança do uso da terra nos recursos hídricos tem sido, muitas vezes, limitada pelo conhecimento das condições de uso da terra no passado. A maioria das publicações neste campo apresenta apenas uma descrição vaga do uso da terra no passado, que geralmente é insuficiente para estudos mais abrangentes. Este estudo apresenta a primeira reconstrução dos padrões históricos de uso da terra na Amazônia, que inclui tantas terras agrícolas quanto pastagens, para o período 1940-1995. Durante este período, a Amazônia experimentou as taxas mais rápidas de mudança do uso da terra no mundo, crescendo quatro vezes, de $193.269 \mathrm{~km} 2 \mathrm{em} 1940$ para 724.899 km2 em 1995. Esta reconstrução é baseada em uma fusão de imagens de satélite e dados do censo, e fornece uma 'x5' conjunto anual de uso da terra em três categorias diferentes (terra cultivada, pastagens naturais e pastagens plantadas) para a Amazônia. Este conjunto de dados será um passo importante para entender os impactos das mudanças no uso da terra nos recursos hídricos da Amazônia.
\end{abstract}

Palavras-chave: Amazônia; Pastagens; Bacias hidrográficas; Mudança no uso da Terra.

Topic: Uso de Recursos Naturais.

Reviewed anonymously in the process of blind peer.

Christiane Cavalcante Leite (ii

Instituto Federal de Alagoas, Brasil

http://lattes.cnpq.br/3119997635801028

http://orcid.org/0000-0002-4218-6654

ccleite@gmail.com

\section{Marcos Heil Costa}

Universidade Federal de Viçosa, Brasil

http://lattes.cnpq.br/8463458737785676

chcl1974@gmail.com

Ranieri Carlos Ferreira de Amorim (iD

Centro Universitário Mauricio de Nassau, Brasil

http://lattes.cnpq.br/6639209700174709

http://orcid.org/0000-0001-8056-7661

rcfamorim@gmail.com
Received: 16/07/2017

Approved: 17/10/2017

\section{Referencing this:}

LEITE, C. C.; COSTA, M. H.; AMORIM, R. C. F.. Estimating historical land use patterns in Amazonia for hydrological studies. Revista IberoAmericana de Ciências Ambientais, v.8, n.4, p.189-197, 2017. DOI: http://doi.org/10.6008/SPC2179-6858.2017.004.0016 


\section{INTRODUCTION}

Land use was generally considered a local environmental issue, but it has become globally important. Changes in forests, croplands, water ways and the atmospheric composition throughout the world are occurring because of the need for food, fibers, water and housing for over 6 billion people. Croplands, pasturelands, forest plantations and urban areas have expanded in recent decades, accompanied by large increases in energy, water and fertilizer consumption and a considerable loss in biodiversity. Although land use practices vary greatly throughout the world, the results are usually the same: acquisition of first-necessity natural resources for human beings, frequently at the cost of degradation in the environmental conditions (FOLEY et al., 2005).

The Amazon is one of the regions of the world where land use is changing faster. According to data from the last agricultural census carried out by the IBGE (Brazilian Institute for Geography and Statistics) planted area in the Legal Amazon grew from 193,269 km² in 1940 to $724,899 \mathrm{~km}^{2}$ in 1995, including permanent and temporary crops, natural and planted pastures, and is currently growing at a rate of about $20,000 \mathrm{~km}^{2} \mathrm{a}$ year. In the meantime, research has shown that changes in the land cover have caused important modifications in the quantity and quality of water resources, in addition to changes in climate (SCANLON et al., 2007).

Man's action changing land use can produce substantial alterations in the terrestrial hydrological processes that include reduction or increase in the mean maximum and minimum flow of a hydrological basin and alteration in water quality. Deforestation to make way for annual or perennial crops increases long-term runoff in a basin because of reductions in evapotranspiration. Studies carried out in small basins $\left(<10 \mathrm{~km}^{2}\right)$ have shown that surface runoff production and flow generally increase in both dry and wet seasons with increase in deforestation and decrease in reforestation (BRUIJNZEEL, 1990; SAHIN et al., 1996), while Costa et al. (2003) showed that the annual mean flow of the River Tocantins in Porto Nacional $\left(178,000 \mathrm{~km}^{2}\right)$ increased $24 \%$ after an increase in agricultural use in the basin. Changes can also be expected in the biogeochemical fluxes in regions where changes in the land cover and land use have been significant (BRANDES et al., 1996; SCANLON et al., 2007).

Some studies have shown that the changes in land cover and land use can also affect the climate. This generally occurs through changes in the radiation balance at the surface, and in the partitioning of the radiation balance in sensible and latent heat fluxes, causing modifications in the atmospheric circulation and climate (BONAN, 2002; FOLEY et al., 2003; COSTA, 2005).

Despite the important relationship between land cover, water resources and climate, there are still relatively few studies that investigate this relationship, especially on a long-term time scale (several decades), necessary to define climate or hydroclimate. One of the reasons for this is that there are few time series of land use available.

With the advances in remote sensing, it is possible to consistently monitor the changes in the land cover from space. However, remote sensing data are available only for the last three decades and therefore are of limited use for studies on changes in the land cover on long term time scales. An alternative is to use 
historical information from the social and economic data collected by census organizations. For this, an extensive database of historical data should be compiled of agricultural land use at national and regional level (states, municipalities, etc.), consistent with the existing political units for each collection period.

Ramankutty et al. (1998) presented an analysis of the global geographic distribution of the area under permanent pasture in 1992 using a uniformly gridded model with a cell size of 5 minutes of latitude by 5 minutes of longitude ( $\sim 9 \mathrm{~km} \times 9 \mathrm{~km}$ at the equator). A worldwide dataset was assembled from a combination of global satellite land cover and agricultural census datasets.

Using a similar approach, Cardille et al. (2002) applied regression tree analysis to find the best fit among the satellite land cover classification data and the information on land use from the agricultural census in Amazonia. They then used this relationship to estimate the density of agricultural areas, per 5 by 5 arcminutes grid cell in the Amazon and Tocantins rivers basins. This fusion of satellite imagery and agricultural census data provided a new geographically explicit description of the cultivated area by agricultural crops, natural and planted pasture.

More important than the quantities, however, is that these datasets come from a new mixture of spatially explicit data based on satellites and census. This approximation can be used as a baseline to project land use patterns forwards or backwards in time. Starting from global spatial patterns of land use obtained for 1992 (described above), Ramankutty et al. (1999) then compiled an extensive dataset of agricultural land use, at national and state level, from 1700 to 1992, and then used the 1992 land use classification to reconstruct land use patterns by permanent agricultural crops from 1992 back to 1700 . This study, although being the first reconstruction of land use for global agricultural crops, also presents some limitations, such as little use of municipality level census data and provided only the land used by croplands, disregarding the land used by pasturelands, which is very important in Amazonia.

In this study, we prepare a geographically explicit land use dataset for Legal Amazonia, Brazil, for the period 1940-1995, by fusing a land cover classification using remote sensing data with historical data series from agricultural census. This is the first reconstruction of land use patterns for Amazonia that includes both croplands and pasturelands. The dataset may be used to in hydrological and climate studies that evaluate the impacts of land-use change on water resources and climate.

\section{DATA AND METHODS}

\section{Data used}

This work is based on two different datasets: 1940 through 1995 agricultural census datasets and a 1995 Amazon basin land use classification. Agricultural census data for the 1940-1995 period was provided by IBGE through Instituto de Pesquisas Econômicas Aplicadas - IPEA. This census dataset is fairly detailed and endeavors to describe land use practices within each municipality in Brazil. The compilation of the census data encompassed the three largest categories: crop areas (permanent and temporary crops), natural pasture and planted pasture. Each category represents the area under the type of agricultural use in each Brazilian municipality. 
To disaggregate the census data and accurately determine the geographic position and the types of land cover throughout the Amazon, we used the land use classification by Cardille et al. (2002). In this study, the authors used a classification based on the AVHRR remote probe (Advanced Very High Resolution Radiometer) that produces data with high time frequency (two satellite passes per day) with an average $1 \times 1$ $\mathrm{km}$ spatial resolution.

Two types of global land cover products based on AVHRR were examined for the Amazon and Tocantins river basins: the DISCover classification (BELWARD et al., 1996) by the International GeosphereBiosphere Program (IGBP), and the global land use classification by the University of Maryland (UMD) [HANSEN et al., 2000]. These land cover databases were developed from monthly NDVI (normalized difference vegetation index) and reflectance values in five AVHRR channels for 1992-1993.

Focused on identifying the land cover in each $1 \mathrm{~km}$ pixel, these classifications are the main step to understand the distribution and abundance of the main biomes and some categories of land use are easily identified. Although these databases have provided useful, high resolution insights about the spatial distribution of most of the land cover during the first half of the 1990s, they explicitly did not include land use, i.e., separations between agricultural crops or pasture.

For this, to properly characterize land use in the Amazon and Tocantins river basins, Cardille et al. (2002) merged these datasets with detailed agricultural census data from Brazilian municipalities and the states of the Amazon countries. The results described a fraction of 5 arc-minutes grid cell dedicated to agricultural activities during the 1990s. The resulting maps conserved only the characteristics of the agricultural census data, but with a much better spatial resolution.

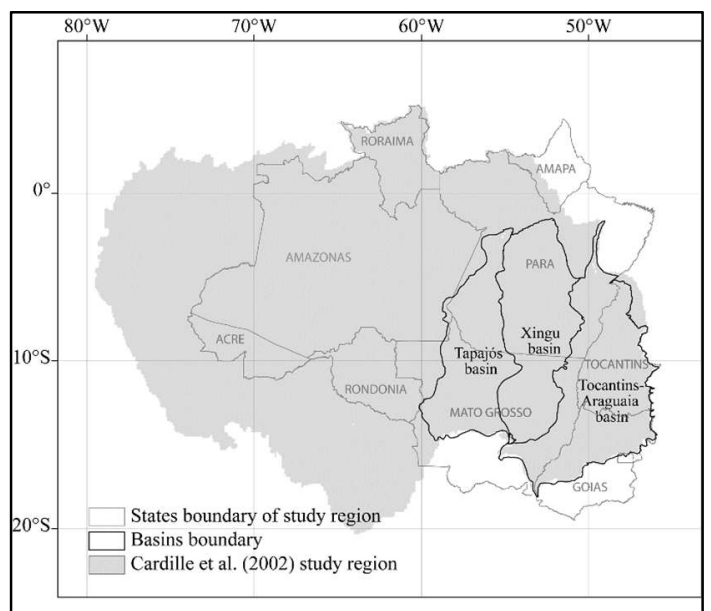

Figure 1: Orientation map. The grey region indicates the Amazon and Tocantins river basins, used by Cardille et al. (2002). Grey lines indicate the Legal Amazonia region, for which census data was used. Final results (Figures $3 \mathrm{e}-3 \mathrm{~h}$ ) are shown for the intersection of both regions. Black lines indicate the limits of the basins Tocantins-Araguaia, Xingu e

Tapajós. Brazilian states are in capital letters.

During the 1990s, the croplands were estimated at $1.7 \times 10^{7}$ ha $(2.5 \%$ of the two basins), natural pasture was estimated at $3.3 \times 10^{7}$ ha ( $4.9 \%$ of the two basins) and planted pasture at $3.3 \times 10^{7}$ ha $(4.9 \%$ of the two basins). The result of the merged dataset is on a satisfactory scale to be incorporated within regionalscale hydrological and atmospheric models and is presented as a regular grid where each cell represents the best fit between the satellite and census data. 
The two datasets used cover slightly different areas (figure 1). The census data covers the region known as Legal Amazonia, which corresponds to the Brazilian states of Acre, Amapá, Amazonas, Mato Grosso, Pará, Tocantins, Rondônia and Roraima. In this study we also include the state of Goiás. The Cardille et al. (2002) land use dataset was prepared for the Amazon and Tocantins basins (grey area in figure 1). Our study region corresponds to the intersection between these two regions.

\section{Historical land use pattern estimates}

The reconstruction of historical patterns of land use for the Amazon involved four different steps: (1) reconstruction of legal Amazon municipalities boundaries for the agricultural census years (1940, 1950, 1960, $1970,1975,1980,1985,1995) ;(2)$ association of census data to the municipalities polygons, producing maps of the fraction of land used by agriculture, per Brazilian municipality, for the period 1940-1995; (3) creation of 5'x5' gridded datasets of land use for the census years, by weighting the 1995 spatial patterns of land use according to the ratio between the census data of the year in question and the census data for 1995; and finally (4) interpolation of the maps to produce yearly estimates of land use.

To reconstruct the land use patterns in the Legal Amazon 1940-1995, it was first necessary to construct the digital network of the municipalities of Legal Amazon in this period. Reconstruction was made from the oldest available municipal digital database of Brazil, prepared by IBGE (situation in 1991). This digital database contains the political and administrative divisions for the entire country, using vector line features to accurately depict state and municipal boundaries. Because municipalities have been successively divided in the 1940-1991 period, the technique to rebuild political boundaries consisted of the fusion, reverse in time, of the municipal polygons from the IBGE 1991 digital municipal network of Brazil according to the reported municipality history and to historical administrative-political maps published by IBGE from 1945 to 1990.

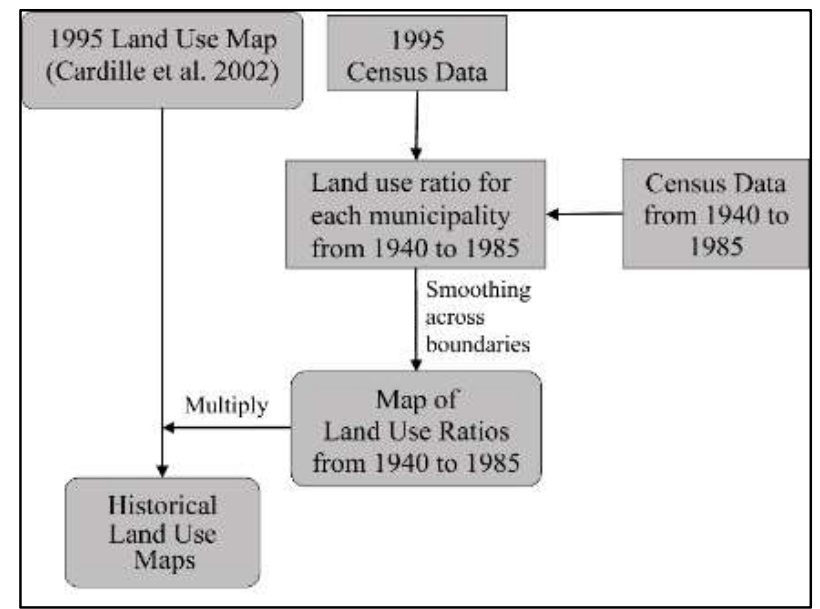

Figure 2: Historical land use reconstruction algorithm.

After obtaining the digital network dataset for each agricultural census year, we assigned the census data to the municipality polygons, and the respective cultivated area in each municipality was calculated detailing the area dedicated to croplands (including annual crops like corn and rice, and perennial crops like avocado and oranges), to natural pasturelands and to planted pasturelands. The fraction of croplands, 
natural pasturelands and planted pasturelands in each municipality was calculated by dividing the cultivated area by the municipality area.

The Cardille et al. (2002) 1995 agricultural land use dataset was used as baseline for developing a simple yet effective land cover change model (figure 2). The models just weights the 1995 spatial patterns of land use according to the ratio between the census data of the year in question and the census data for 1995. The model produced a time series of the spatial distribution of historical land use data within a municipality for every census year.

\section{RESULTS AND DISCUSSION}

\section{Spatial patterns of land use}

Figure 3 shows an example of the datasets produced for the year 1980. Similar maps for the other census years are available, but are not discussed here. Figures $3 a$ through $3 c$ show the proportion of the each type of agricultural land use (natural pastureland, planted pastureland, cropland), for each municipality polygon, while Figure $3 d$ shows the proportion of all types of agriculture land use per polygon. Figures $3 e$ through 3 h show the same information gridded to a $5^{\prime}$ grid, according to the methodology described above.

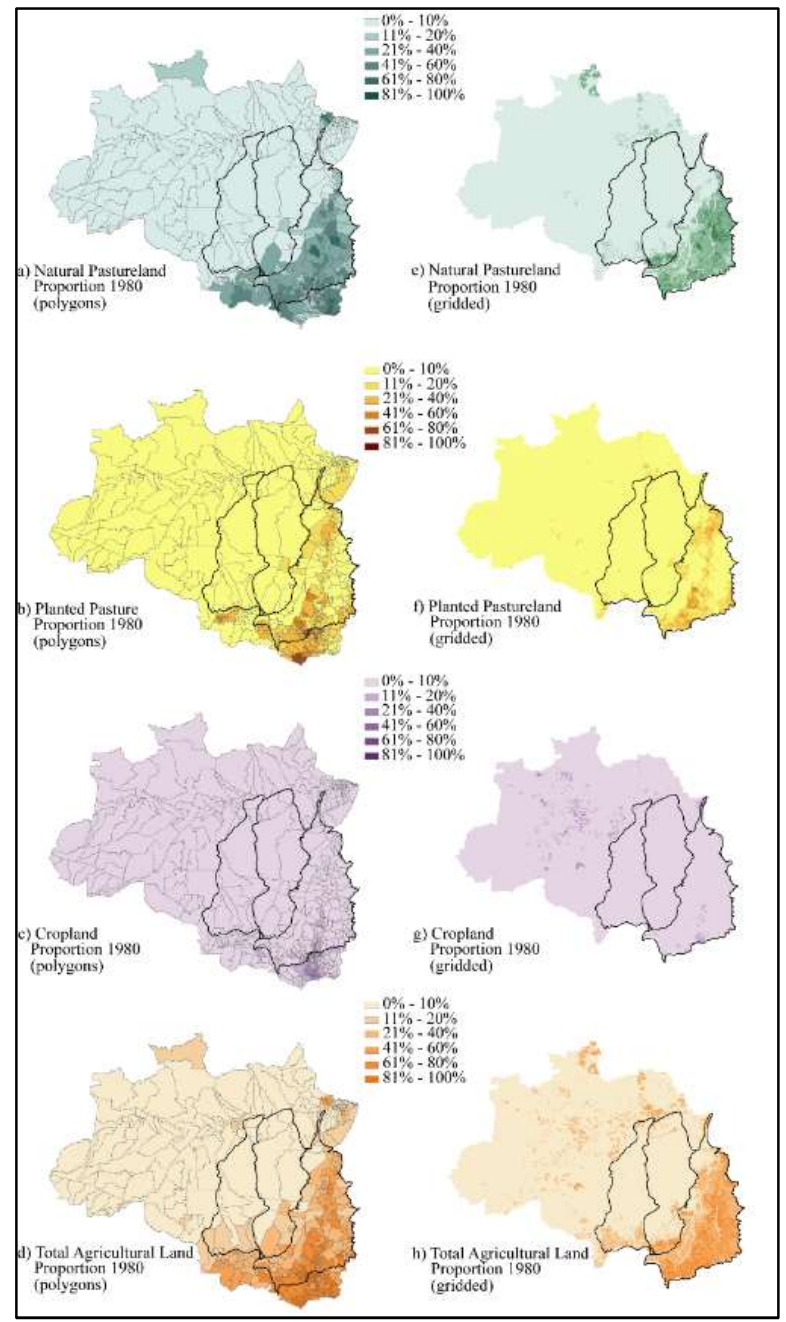

Figure 3: Proportion of land use in 1980. (a) natural pasture in each polygon; (b) planted pasture in each polygon; (c) annual and perennial cropland in each polygon; (d) total agriculture land use in each polygon; (e) natural pasture in

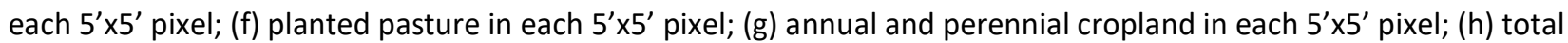
agriculture land use in each $5^{\prime} \times 5^{\prime}$ pixel. Black lines indicate the limits of the basins. 
In 1980, the dominant land use type in Amazonia was natural pasture (Figures 3a and 3e), with a higher density in the states of Goiás and Tocantins, occupying about $30 \%$ of the area of these two states, and extending throughout the entire Tocantins-Araguaia basin and along the southern part of the Xingu basin. Another region with remarkable natural pasture land use is the northern part of the state of Roraima. In the southern Tapajós basin, there are a few pixels with proportions that reach $11 \%$ of natural pastureland. Planted pastures are concentrated in the eastern and southern parts of the region of study, specially along the Tocantins-Araguaia basin (Figures $3 \mathrm{~b}$ and $3 \mathrm{f}$ ). Croplands are rare in this region, representing only $1.3 \%$ of the region in study in 1980, is scattered throughout the basin, and nearly absent in the Xingu and Tapajós basins (Figures 3c and 3g).

Figure $3 d$ shows the total density of land use for agriculture (the sum of Figures $3 a, 3 b$ and $3 c$ ), which occupies 589,665 km² (about 11.6\% of the study area), and concentrated in southeastern Amazonia, covering most of the states of Tocantins and Goiás e southern Mato Grosso. In these regions, most of the municipalities show agriculture land use proportions above $60 \%$ the municipality area. Figure $3 \mathrm{~h}$ shows a disaggregated version of Figure $3 d$, showing that the agriculture land use is nearly-uniformly distributed through the Tocantins-Araguaia basin, is significative in the southern Xingu basin and scattered throughout the rest of the study region.

\section{Evolution of land use in Tocantins-Araguaia, Xingu and Tapajós Rivers Basins}

Three large basins are totally encompassed by the study region: the Tocantins-Araguaia system, the Xingu basin and the Tapajós basin (Figure 1), with drainage areas of $767,311 \mathrm{~km}^{2}, 519,461 \mathrm{~km}^{2}$, and 534,353 $\mathrm{km}^{2}$, respectively. The Tocantins-Araguaia is an independent basin that shares the Amazon River delta, while the Xingu and the Tapajós rivers are tributaries of the Amazon River.

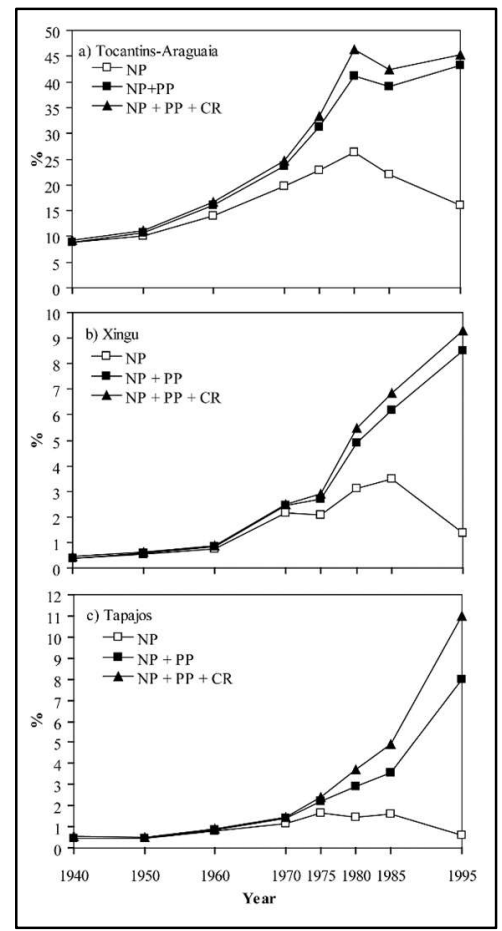

Figure 4: Evolution of the several types of land use in each basin. (a) Tocantins-Araguaia (b) Xingu (c) Tapajós. NP indicates natural pastures, PP planted pastures, and CR croplands. 
Figure 4 shows the temporal evolution of the three categories of land use for these three basins, for the period 1940-1995. Each point in this figure is obtained through the spatial integration of the correspondent land use in maps like Figure 3. White squares represent natural pastureland (NP) proportion, black squares represent total pastureland proportion (NP+PP), and black triangles represent the total agricultural land proportion (PP + NP+CR).

Figure 4a indicates that, within the Tocantins-Araguaia basin, there was an exponential increase in agricultural land use from $9 \%$ in 1940 to $46 \%$ in 1980, remaining relatively stable after that. Natural pasturelands dominated until 1980, when they started to be heavily replaced by the more productive planted pasturelands. In the Xingu and Tapajós basins (Figures $4 \mathrm{~b}$ and 4c), land use has also grown fast in the period, but did not exceed $10 \%$ of the basin area. The same Tocantins-Araguaia trend is observed here: dominance of natural pasturelands until around 1980, when they were increasingly replaced by planted pasturelands. In both Xingu and Tapajós basins, land use is still in the exponential growth phase, which suggests fast growth rates for many years to come.

\section{CONCLUSIONS}

Despite the increasing knowledge of the impacts of land use and land cover change in the quantity and quality of water resources, there is still a lack of studies that explicitly describe historical practices of land use. In this study we report estimates of historical patterns of land use for the Brazilian part of the Amazon basin, as well as the Tocantins-Araguaia basin, regions that have experienced the fastest rates of changes in land use in the past decades. This is the first historical land use product that includes both croplands and pasturelands. The results presented here are preliminary, as this is a work in progress. The second step of this work will produce similar maps for Brazil, and a third step aims at South America.

Although we now have historical estimates of the distribution of cropland and pastures for Amazonia, a few caveats need to be noted. First, a limitation of this study is that the baseline used, from Cardille et al. (2002), is restricted to the Amazon and Tocantins basins, which will limit the expansion of this product to the rest of Brazil and South America. Other global cropland products available (RAMANKUTTY et al., 1998) are not suitable as a baseline, because they do not include pasturelands. Future versions of this product, that will cover wider areas, will be based on the recently developed global cropland and pastureland dataset of (RAMANKUTTY et al., 1998)

Second, census data have their inherent uncertainty. In a few municipalities, the reported planted area was higher than the municipality area. This may be due to double cropping in some farms, but may also represent errors in the dataset. In other cases, outliers were noted in the time series for the same municipality. These cases were carefully examined in the census dataset, and in some cases filtered out and replaced by estimated values.

Third, our datasets have uncertainties related to the fact that we are merging two different observation systems - remote-sensing based and ground based. Remote sensors can only observe land cover, i.e., the top of the vegetative canopy, and retrieve little information on the actual type of land use. The 
ground-based land use data, on the other hand, may include information that is incompatible with the remote sensing product. For example, while the cropland census data include permanent crops such as tree crops, it is not clear whether the remote sensing classifications consider tree crops as forests or whether they classify them as deforested land.

Concluding, despite important uncertainties, we need to make progress toward developing new methods to characterize the historical spatial patterns of agricultural lands. There is great demand by the global environmental change community to understand how agricultural lands are changing and evaluate their implications in water resources, climate, and biogeochemical cycling, among others. A classical application is the attribution of the causes of climate change.

Climate change may have natural and anthropogenic causes: natural causes include solar variability and volcano eruptions, while anthropogenic causes include changes in greenhouse gas concentrations, and change in land use due to urbanization and agriculture. The dataset presented here will be useful to help attribute causes of climate change in this region. Other applications are the investigation of the impacts of changes in land cover and land use in the water resources in the region.

\section{REFERENCES}

BRANDES, J. A.; MCCLAIN, M. E.; PIMENTEL, T. P. N.. Evidence for the origin and cycling of inorganic nitrogen in a small Amazonian catchment. Biogeochemistry, v.34, p.4556, 1996.

BRUIJNZEEL, L. A.. Hydrology of moist tropical forests and effects of conversion: A state-of-knowledge review. Paris: UNESCO International Hydrological Programme, 1990.

CARDILLE, J. A.; FOLEY, J. A.; COSTA, M. H.. Characterizing patterns of agricultural land use in Amazonia by merging satellite classifications and census data. Global Biogeochemical Cycles, v.16, n.1386, 2002. DOI: http://doi.org/10.1029/2000GB001386

COSTA, M. H.. Large-scale hydrological impacts of tropical forest conversion. In: BONELL, M.; BRUIJNZEEL, L. A.. Forest, Water and People in the Humid Tropics. Cambridge: Cambridge University Press, 2005. p.590-597.

COSTA, M. H.; BOTTA, A.; CARDILLE, J. A.. Effects of largescale changes in land cover on the discharge of the Tocantins River, Southeastern Amazonia. Journal of Hydrology, v.283, p.206-217, 2003.

FOLEY, J. A.; COSTA, M. H.; DELIRE, C.; RAMANKUTTY, N.; SNYDER, P.. Green surprise? How terrestrial ecosystems could affect earth's climate. Frontiers in Ecology and the Environment, v.1, p.38-44, 2003.
FOLEY, J. A.; DEFRIES, R.; ASNER, G. P.; BARFORD, C.; BONAN, G.; CARPENTER, S. R.; CHAPIN, F. S.; COE, M. T.; DAILY, G. C.; GIBBS, H. K.; HELKOWSKI, J. H.; HOLLOWAY, T.; HOWARD, E. A.; KUCHARIK, C. J.; MONFREDA, C.; PATZ, J. A.; PRENTICE, C.; RAMANKUTTY, N.; SNYDER, P. K.. Global Consequences of Land Use. Science, v.309, p.570-574, 2005.

RAMANKUTTY, N.; EVAN, A. T.; MONFREDA, C.; FOLEY, J. A.. Farming the Planet. Part 1: The Geographic Distribution of Global Agricultural Lands in the Year 2000. Global Biogeochemical Cycles, v.22, 2008. DOI: http://doi.org/10.1029/2007GB002952

RAMANKUTTY, N.; FOLEY, J. A.. Characterizing patterns of global land use: An analysis of global croplands data. Global Biogeochemical Cycles, v.12, p.667-685, 1998.

RAMANKUTTY, N.; FOLEY, J. A.. Estimating historical changes in global land cover: Croplands from 1700 to 1992. Global Biogeochemical Cycles, v.13, p.997-1027, 1999.

SAHIN, V.; HALL, M. J.. The effects of aforestation and deforestation on water yields. Journal of Hydrology, v.178, p.293-309, 1996.

SCANLON, B. R. I.; JOLLY, M. S.; ZHANG, L.. Global impacts of conversions from natural to agricultural ecosystems on water resources: Quantity versus quality. Water Resources Research, v.43, 2007. DOI: http://doi.org/10.1029/2006WR005486 